\section{PERONISTAS Y MILITARES. \\ UNA VIEJA RELACIÓN \\ EN UN NUEVO CONTEXTO}

\author{
PERONISTS AND THE MILITARY.
}

AN OLD RELATIONSHIP IN A NEW CONTEXT

ANABELLA GORZA .

Anabella Gorza es becaria doctoral del CONICET e investigadora del Centro Interdisciplinario de Investigaciones en Género del Instituto de Investigaciones en Humanidades y Ciencias Sociales de la Facultad

\section{Resumen}

Este artículo aborda el levantamiento cívico militar encabezado por el general Miguel Ángel Iñíguez, ocurrido el 30 de noviembre de 1960. Este alzamiento fue el último intento de golpe de Estado peronista puesto en práctica, como estrategia para la recuperación del poder luego del derrocamiento de Perón en 1955. Las repercusiones que generó se filtraron en los debates de la época acerca del mantenimiento o no del estado de sitio y del Plan CONINTES, del otorgamiento de la legalidad al peronismo, del proceso de normalización de la CGT y del rol que los militares debían cumplir en la sociedad. A su vez, su estudio, nos ha permitido reflexionar sobre la relación de larga data entre Ejército y peronismo, y la reactualización de esta relación durante el período de la Resistencia, y la cuestión, mucho más amplia, de las relaciones entre civiles y militares que caracterizaron a la época. de Humanidades y Ciencias de la Educación - Universidad Nacional de La Plata. e-mail: cinig@fahce.unlp.edu.ar

\section{Summary}

This article addresses the civic-military uprising led by General Miguel Ángel Iñíguez, which took place on November 30, 1960. This insurrection is the last peronist attempt of coup d'état as strategy to return to power after the overthrow of Perón in 1955. This uprising had an effect on the debates of that time about maintaining or not the state of siege and the CONINTES Plan, granting full legal recognition to the peronist movement, as well as the debates concerning the process of normalizing the CGT and the role that Armed Forces should play in society. This study has also helped us to reflect on the old standing relation between Peronism and the Army and this new instance of that relation during the period of the Resistance; and the broader issue of the civicmilitary relations that characterized the period. 